\title{
Junior high school students' perceptions of physical education subjects: An instrument development
}

\author{
Mu'arifin ${ }^{\text {abcde }}$ \\ Universitas Negeri Malang, Indonesia \\ Received: 10 June 2021; Accepted 09 September 2021; Published 08 December 2021
}

Ed 2021; 6(3): 394-402

\begin{abstract}
Students' perception of the concept of physical education is one of the determinants of success in learning. Physical activity characteristics that are dominated by physical activity are often perceived as inaccurate, resulting in a low appreciation of it. This study aimed to develop an instrument to measure students' perceptions of the concept of physical education. This research is development research involving 693 junior high school students in Pacitan, Tulungagung, and Kediri districts. To measure the validity of the instrument, the biserial point correlation technique was used with the help of Microsoft Excel, and to measure the reliability of the instrument used the Cronbach Alpha analysis technique with the help of SPSS version 23. The results obtained were the compilation of 71 statements that could be used to measure students' perceptions of the concept of physical education. Teachers can use the results of this development to measure perceptions, especially junior high school students, about the concept of physical education subjects so that teachers can prepare learning materials based on the perception data obtained. This development research only measures perceptions at the junior high school level, it is hoped that further research can involve motivation and implementation of physical education learning at various levels of education.
\end{abstract}

Keywords: Concepts; physical education; perceptions

https://doi.org/10.25299/sportarea. 2021.vol6(3).7068

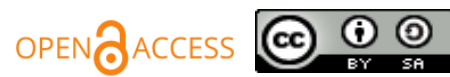

Copyright @ 2021 Mu’arifin

Corresponding Author: Mu'arifin, Department of Sports Education, Faculty of Sports Science, Universitas Negeri Malang, Malang, Indonesia

Email: muarifin.fik@um.ac.id

How to Cite: Mu'arifin. (2021). Development of instruments to measure junior high school students' perceptions of the concept of physical education subjects. Journal Sport Area, 6(3), 394-402. https://doi.org/10.25299/sportarea. 2021.vol6(3).7068

Authors' Contribution: a - Study Design; b - Data Collection; c - Statistical Analysis; d - Manuscript Preparation; e - Funds Collection

\section{INTRODUCTION}

Physical education is described "as the only curriculum subject whose focus is on combining physical body and competence with values-based learning and communication, providing a learning gateway for cultivating the skills needed to succeed in the 21st century" (United Nations Educational, Scientific and Cultural). Organization [UNESCO] (McLennan \& Thompson, 2015). This shows that physical education subjects are very important for students in achieving growth and development as expected. The hallmark of physical education is movement learning. Meanwhile, according to Stevens and Culpan, (2021)aa physical education is closely related to physical activity in the form of human movement. All physical learning activities are motion-based. By moving, students will gain varied experiences, both in terms of the variety of 
motion, efforts/processes of struggling in achieving movement skills, or social interaction in learning motion and in displaying their movement abilities in an event/competition (Stevens \& Culpan, 2021).

Ontologically, the field of study of physical education is a moving human being. Humans do a movement basically not only for the interests related to the movement itself, but also for other interests, for example for health and sleep quality (Xiong et al., 2021). Physical education learning prioritizes physical activity to achieve learning objectives (Pujianto et al., 2021). Although in essence carrying out physical activities or carrying out movement tasks, in essence, the movement tasks are more functioned as a medium for educating students, namely to optimize all students' potential. In this regard, McEvoy et al. (2017) stated that physical education provides opportunities for students to learn various activities that foster as well as develop physical, mental, social, emotional, and moral potential. Furthermore, it is in the context of achieving goals in general.

The essence of physical education is to educate students through movement. By carrying out movement tasks, students will gain rich experience to optimize all their potential. The essence of physical education is to educate students through movement in the hope that students will gain rich experiences to optimize all their potential (Di Tore et al., 2016). Physical education classes are very important for children's physical, motor, and social development (Teodora-Mihaela et al., 2017). Motor skills and motor quality can be developed using methods applied in physical education classes.

At the functional level, physical education is directed at the growth of harmony between physical and mental development (Curtis \& Braga, 2018). Physical education learning is not only theoretical and involves only physical elements, but also fosters mental, intellectual, emotional, and social elements (MroczekADEF et al., 2017; Whitehead, 2013). Furthermore, according to Esteban-Cornejo et al., (2017) revealed that students' physical, mental, and emotional developments can be thoroughly developed through physical education with physical activity.

As a compulsory subject in schools, the purpose of physical education is integrated with educational goals (Lengkana \& Sofa, 2017; Pambudi et al., 2019), the growth and development of all potentials possessed by students, so that they can become qualified, intelligent, and competitive individuals. According to Kwon and Block (2017), physical education cannot be separated from education in schools, and aims to improve students' attitudes, knowledge, and skills. In particular, according to Portwood (2019) the purpose of physical education is to develop control of body movements. Mastery of movement control will only be obtained when students are diligent in practicing (Wang et al., 2017), both of in individual and in groups. In such a training process, students will directly gain valuable experience in interacting, communicating, collaborating, and competing with other students (Beni et al., 2017). In such a context, physical education provides a variety of constructive learning experiences for students to instill positive values such as honesty, perseverance, respect, responsibility, respect, and appreciation (Marheni et al., 2019; Muhtar \& Dallyono, 2020; Suherman, 2018). More broadly, the purpose of physical education is expressed by McEvoy et al. (2017), namely providing opportunities for children to learn various activities that foster and develop children's potential, both in physical, mental, social, emotional and moral aspects.

In carrying out the task of movement to achieve broader goals, basically students not only activate the physical aspect, but also involve mental, moral, social, intellectual, and even spiritual aspects (McEvoy et al., 2017). Thus, physical education is an educational process using learning experiences in the form of physical activities, sports, and games that are systematically arranged to increase students' physical growth, motor skills, social, moral, and emotional (Harvey et al., 2014). A logical consequence of the complexity of the goals to be achieved, further studies prove that physical education learning is based on a multidisciplinary approach, which involves concepts from pedagogy, physics, mathematics, natural sciences, social sciences, and kinesiology to ensure its success (Penney \& Chandler, 2000).

Basically the concept is an ability that can be measured through an instrument (Rahman et al., 2018). The level of understanding of the concept of course between students is different from one another, therefore a concept understanding cannot be dichotomy based on age or level of education (Fitron, 2020). An understanding of the concept of physical education needs to be instilled in students as the main subject. The correct perception of the concept of physical education will be able to increase the enthusiasm of students in 
participating in physical education learning (Mashuri, 2017). The information is processed by sorting, interpreting, analyzing, and integrating the stimuli carried by the senses and the brain (Feldman, 2012). Perception always begins with a sensing process which is part of the process of receiving information or a stimulus through the senses (Mashuri, 2017). The information processing is done by sorting, interpreting, analyzing, and integrating the stimuli brought by the senses and the brain (Feldman, 2012). The perception process takes place when a person receives a stimulus from the outside world and then enters the brain so that a thought process occurs which ultimately results in understanding (Sarwono, 2010).

With regard to students' behavior Triatna (2015) concludes that perception is a process that occurs within the individual when responding to his environment through thought and feeling processes which then become the basis for consideration of his behavior. The behavior of students in participating in physical education learning can be built constructively by understanding them about the importance of this lesson. With the right perception, the right behavior will also be obtained, because according to Pieter (2018), perception is one of the factors causing the emergence of behavior, in addition to factors of knowledge, attitudes, traits, interests, personality, learning process, quantity and quality of rewards, and the environment. On a broader scale, students' perceptions are needed to show the relationship between the school environment and educational outcomes (Edgerton et al., 2011). For this reason, it is necessary for students to have the right perception of the position of the school environment, so that in order to obtain good learning processes and outcomes, students are given the experience to interact with the environment intensively.

The right and correct interpretation of the concept of physical education helps students to understand that this subject is very strategic and important in educating students. Correct understanding like this will help effectiveness in achieving the learning objectives of physical education. This is supported by the opinion of Mutodi and Ngirande (2014) which states that "Students' perceptions of their school environments and the relationship with educational outcomes". Likewise, Wang et al., (2010) stated that with the right perception, it will be able to increase intrinsic motivation in carrying out physical education.

Several studies on students' perceptions of physical education have been carried out by several previous researchers, both of students' perceptions of physical education at the high school level (Fitron, 2020; Mashuri, 2017), and even measuring non-physical education teachers' perceptions of physical learning (Redawati \& Asnaldi, 2017). In this study, the researchers attempted to develop an instrument that could truly measure the junior high school students' perceptions of physical education. The preparation of the instrument began with a workshop forum and Focus Group Discussion (FGD). The difference between this study and previous research is that the instrument is focused on measuring students' perceptions of the understanding, goals, and characteristics of physical education activities. In addition, in this study, researchers developed a new model of perception measurement instrument whose validity was tested using the biserial point correlation technique, and to measure the relieability of the instrument used internal consistency using the Kuder Richardson technique, namely the KR 20 test. On this basis, this study aimed to develop an instrument which is focused on measuring students' perceptions of the meaning, objectives, and characteristics of physical education activities. With the preparation of this instrument is expected to be used as a measuring tool to assess students' perceptions of the concept of physical education.

\section{METHOD}

Research and Development design (Research and Development) referring to Borg and Gall (1983) was used in the preparation of this perception instrument. The procedures used are 1) reviewing the variables to be measured into details of sub-variables and their indicators, 2) determining the type of instrument to be compiled, 3) compiling an instrument grid in accordance with the established indicators, 4) compiling questions / statement according to the grid, 5) testing the readability of the instrument (expert test), 6) testing the validity of the instrument to the expert, and 7) testing the validity and reliability of the instrument to the target (field test).

The preparation of the grid (Table 1) and initial instruments was carried out in the workshop forum and Focus Group Discussion (FGD). Focus Group Discussion is the collection of data and information 
related to specific problems through focused group discussions (Siregar, 2018). In this FGD, the researcher conveyed the idea and the initial product of the instrument to be studied together, so as to get an assessment and input for improvement. The FGD involved 4 lecturers of the research team and 4 final semester undergraduate students. The 4 lecturers are experts in the field of physical education learning and evaluation of physical education, while students are involved in conveying opinions about physical education.

The expert test phase involved 3 relevant lecturers, while the field test involved 693 junior high school students in Pacitan, Tulungagung and Kediri districts. The selection of these subjects was based on the sampling technique chosen by the researcher, namely purposive sampling, this is because the researchers chose schools that implemented the 2013 curriculum (K-13). To measure the validity of the instrument used biserial point correlation technique with the help of Ms. Excel and for reliability test using Cronbach Alpha test with the help of SPSS.

Table 1. Grid of Research Instruments

\begin{tabular}{|c|c|c|}
\hline Variable & Indicator & Sub-Indicator \\
\hline \multirow[b]{3}{*}{$\begin{array}{l}\text { Physical } \\
\text { Education } \\
\text { Concept }\end{array}$} & $\begin{array}{l}\text { Definition of Physical } \\
\text { Education }\end{array}$ & $\begin{array}{l}\text { - An integral part of education } \\
\text { - Using the media for physical activity/ motion/ human movement } \\
\text { - } \quad \text { Optimizing the full potential of students }\end{array}$ \\
\hline & Purpose of Physical Education & 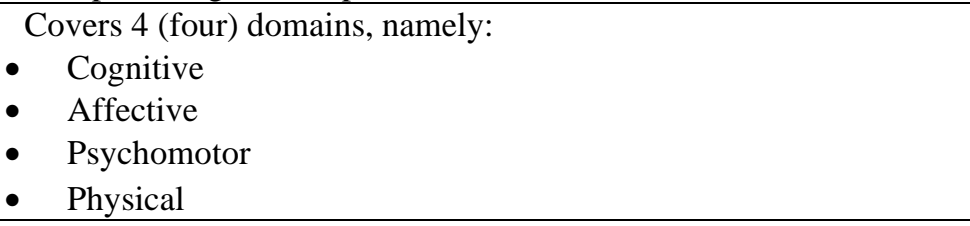 \\
\hline & $\begin{array}{l}\text { Characteristics of Physical } \\
\text { Education Activities }\end{array}$ & $\begin{array}{l}\text { - General characteristics of physical education learning: } \\
\text { 1. Fun } \\
\text { 2. Busy } \\
\text { 3. Intact } \\
\text { 4. Flexible/modification } \\
\text { - Special characteristics: } \\
\text { 1. Games and sports } \\
\text { 2. Development activities } \\
\text { 3. Self test } \\
\text { 4. Rhythmic activity } \\
\text { 5. Aquatic activity } \\
\text { 6. Education outside the classroom } \\
\text { 7. Health }\end{array}$ \\
\hline
\end{tabular}

\section{RESULTS AND DISCUSSION}

This study aims to develop an instrument to measure students' perceptions of the concept of physical education. The workshop to develop the initial grid and instruments resulted in the decision that the level of students' perceptions of the concept of physical education was measured using a closed inventory questionnaire and using the Guttman scale. This scale is very appropriate to obtain student responses in a clear, firm, and consistent manner. Students' responses are carried out by giving a check list in the provided column, namely column B (correct answer) and column S (wrong answer). The initial instrument produced in the workshop consisted of 82 items consisting of 27 items regarding the definition of physical education, 28 items regarding the objectives of physical education, and 27 items regarding the characteristics of physical education activities.

Testing by experts on 82 items was carried out to determine the level of readability of the instrument and the suitability (validity) of the items with the concept of physical education. Testing by experts is carried out openly. Three experts were given the opportunity to study the instrument then were given the freedom to make revisions, criticisms, or suggestions written directly on the instrument script. The results of the expert revision (Table 2) were rediscussed in a limited discussion or FGD with the main objective of clarifying and confirming expert input, so that consensus was obtained on all expert inputs in improving the instrument. 
Table 2. Experts' Revised Results

\begin{tabular}{|c|c|c|}
\hline No & Aspect & Feedback/Suggestions \\
\hline 1 & Legibility & $\begin{array}{l}\text { a. Clear introductory presentation that motivates respondents } \\
\text { b. Font usage and typing } \\
\text { c. Avoid foreign words/terms } \\
\text { d. Use simple sentences } \\
\text { e. Selection of standard fonts and sizes } \\
\text { f. The layout of each item of the instrument } \\
\text { g. Clear instructions for filling out the instrument }\end{array}$ \\
\hline 2 & Suitability & $\begin{array}{l}\text { a. Conformity of the description of the indicator with the variable } \\
\text { b. Conformity of the description of the sub-indicator with the indicator } \\
\text { c. The suitability of each item of the instrument with the sub-indicator } \\
\text { d. The suitability of the statement of each item of the instrument with the characteristics } \\
\text { of the respondent }\end{array}$ \\
\hline 3 & $\begin{array}{l}\text { Conclusion from Written } \\
\text { Notes and Discussion } \\
\text { Results }\end{array}$ & $\begin{array}{l}\text { a. It is necessary to consider the characteristics of the respondents (junior high school } \\
\text { students), consequently the use of words/sentences is made simple so that they are } \\
\text { easy to understand. } \\
\text { b. It is necessary to give an introductory sentence about the intent and purpose of filling } \\
\text { out this instrument, so that the respondent objectively fills it in, and does not feel } \\
\text { worried } \\
\text { c. Instructions for filling out the instrument need to be clearly formulated } \\
\text { d. In the instrument grid, it is necessary to explain the concept of physical education into } \\
\text { indicators that are in accordance with the theory } \\
\text { e. The translation of indicators into statement items is formulated in the form of } \\
\text { statements, and by using simple language, and avoiding foreign terms } \\
\text { f. The order in which the statement items are presented starts with the meaning of } \\
\text { physical education, after that a statement about the objectives, and continues with the } \\
\text { characteristics of the activities. } \\
\text { g. The contents of the instruments that are compiled refer to the curriculum that applies } \\
\text { and is implemented in schools }\end{array}$ \\
\hline
\end{tabular}

Field tests were carried out to measure the level of validity and reliability of 82 items that had been tested by experts. Based on data analysis using the biserial point correlation technique, the results obtained are 11 items that are not valid, so that the valid instrument consists of 71 items, namely 26 items regarding the definition of physical education, 30 items regarding the objectives of physical education, and 15 items regarding the characteristics of physical education activities. The results of the validity test with biserial points can be seen in Appendix 1 (attached). The results of the validity test showed that of the 82 questions there were 11 questions that were invalid or the value of $r_{\text {count was }}$ less than 0.05 .

The results of the reliability test using Cronbach Alpha obtained a value of 0.756 with $\mathrm{N}=71$ the

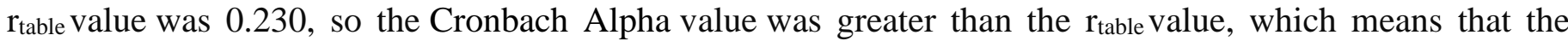
question items are declared reliable or reliable. The results of the Cronbach Alpha test can be seen in Table 3 below.

Table 3. Reliability Test Using Cronbach's Alpha

\begin{tabular}{cccc}
\hline Cronbach's Alpha & Cronbach's Alpha Based on Standardized Items & N of Items \\
\hline .756 & .775 & 71 \\
\hline
\end{tabular}

The final result of this research is the arrangement of instruments to measure students' perceptions of the concept of physical education. A good instrument must meet the theoretical requirements and be supported by reinforcing empirical data to ensure its validity and reliability. Theoretically, this instrument is prepared on the basis of a study of the latest and relevant theories, as well as through analytic actions in the form of elaboration of the perception variable on physical education, so that indicators and instrument grids are arranged. Empirical evidence was strengthened by using expert judgment techniques and statistical analysis techniques that were in accordance with the objectives. Regarding instruments to measure students' perceptions of the concept of physical education, so far there has been no research and development that is really aimed at compiling valid instruments, but some research has actually revealed the results of students' 
perceptions of the concept of physical education (Asnur, 2016; Boihaqi \& Fakhrullah, 2019; Mashuri, 2017). Some of these studies rely on previous research instruments or adopt previous research. This instrument is a product that can be used by anyone and has gone through a process in such a way that this instrument can actually be used to measure students' perceptions of the concept of physical education.

The instrument of perception of the concept of physical education is translated into 3 themes, namely understanding, objectives, and characteristics of physical education activities. Based on this, 71 items have been compiled consisting of 26 items regarding the definition of physical education, 30 items regarding the objectives of physical education, and 15 items regarding the characteristics of physical education activities.

This instrument about perception is important to be arranged as an effort to increase students' appreciation of physical education subjects (Mashuri, 2017). Empirical conditions show that this subject is often misunderstood by most educators. Physical education subjects are seen as a distraction from the situation and condition of students who sit in class for too long (Rahman et al., 2020), so that their existence is considered an unimportant field and does not need to be managed seriously. It is feared that such conditions, coupled with a less supportive environment will affect students' perceptions, because environmental factors such as study groups, parents/family, peers, social groups, places of residence, and so on have an influence on students' perceptions of academic performance (Agyeman et al., 2016).

Students' perceptions of physical education subjects will determine the level of understanding, attitudes, and behavior of students in carrying out movement tasks that characterize this subject. Students' perceptions are closely related to learning outcomes, because students who have good perceptions will generally be able to optimize the learning process independently to improve their learning outcomes (Marhento, 2015; Najichun \& Winarso, 2017; Saputra \& Syafik, 2016). In learning mathematics, Dauda et al. (2016) stated that student perceptions are factors that affect student performance.

The right perception of the concept of physical education will result in students' correct understanding of the meaning and significance of physical education. With such an understanding, students will understand and appreciate physical education as a strategic medium for educating students. In addition, according to Wardana and Hairunnisa (2018), perceptions can affect students' interest in making a choice. In the context of physical education learning, with the right perception, students are able to determine the correct decision in carrying out the given motion tasks, namely in accordance with the principles of physical education learning that is carried out in a fun, active, and hit all aspect of the students' potential.

Several studies related to the results of students' perceptions of physical education subjects have been carried out, especially at the high school level (Asnur, 2016; Boihaqi \& Fakhrullah, 2019; Mashuri, 2017; Rahman et al., 2020), which of course also affects achievement. learning and student motivation (Saputra \& Syafik, 2016; Wardana \& Hairunnisa, 2018). Physical education subjects are considered as useful subjects for maintaining physical fitness and keeping the mind fresh (Asnur, 2016). Some of these findings are important for this study which seeks to facilitate physical education teachers to investigate students' perceptions of special physical education subjects for junior high school students.

\section{CONCLUSION}

This study aims to develop a test instrument for students' perceptions of the subjects of physical education for junior high school students. The findings of this study are the composition of 71 items consisting of 26 items about the definition of physical education, 30 items about the objectives of physical education, and 15 items about the characteristics of physical education activities. This instrument can be used for physical education teachers at the Junior High School level to determine students' perceptions of physical education subjects.

With the arrangement of an instrument to measure the level of students' perceptions of the concept of physical education, this instrument needs to be immediately used in massive research to measure student perceptions. This study aims to measure students' perceptions and at the same time test the validity and reliability of the instrument in a wider field. In addition, repeated studies of this instrument are needed, both of theoretically and empirically, especially in diverse populations, so that a truly reliable instrument will be obtained and the level of usefulness is more widespread and significant. 
The limitation of this research is that researchers only develop instruments to measure perceptions, it is expected that further research can investigate interest in learning and also needs to get perceptions from teachers of subjects other than physical education subjects.

\section{CONFLICT OF INTEREST}

The authors have no conflict of interest to declare.

\section{REFERENCES}

Agyeman, G. A., Frimpong, E. A., \& Ganyo, E. R. (2016). Students' perception of socio-cultural factors affecting academic performance. American Scientific Research Journal for Engineering, Technology, and Sciences (ASRJETS), 19(1), 19-24.

Asnur, A. (2016). Persepsi Siswa terhadap Mata Pelajaran Penjas ditinjau dari Minat dan Gender pada Kelas XI Agama MAN 3 Makassar. Universitas Negeri Makassar.

Beni, S., Fletcher, T., \& Ní Chróinín, D. (2017). Meaningful experiences in physical education and youth sport: A review of the literature. Quest, 69(3), 291-312. https://doi.org/10.1080/00336297.2016.1224192

Boihaqi, B., \& Fakhrullah, F. (2019). Persepsi Siswa Terhadap Mata Pelajaran Pendidikan Jasmani Olahraga dan Kesehatan Pada Siswa SMA Negeri 1 Unggul Darul Imarah Kabupaten Aceh Besar. Serambi Konstruktivis, 1(2). https://doi.org/10.32672/konstruktivis.v1i2.1141

Borg, W. R., \& Gall, M. D. (1983). Educational research: an introduction. Longman, Inc.

Curtis, H., \& Braga, L. (2018). Slacklining in Physical Education: A Nontraditional Approach to Balancing Children's Body and Mind. Strategies, 31(2), 54-56. https://doi.org/10.1080/08924562.2018.1418573

Dauda, B., Jambo, H. E., \& Umar, M. A. (2016). Students' Perception of Factors Influencing Teaching and Learning of Mathematics in Senior Secondary Schools in Maiduguri Metropolis, Borno State, Nigeria. Journal of Education and Practice, 7(20), 114-122.

Di Tore, P. A., Schiavo, R., \& D'Isanto, T. (2016). Physical education, motor control and motor learning: Theoretical paradigms and teaching practices from kindergarten to high school. Journal of Physical Education and Sport, 16(4), 1293-1297.

Edgerton, E., McKechnie, J., \& McEwen, S. (2011). Students' perceptions of their school environments and the relationship with educational outcomes. Educational and Child Psychology, 28(1), 33-45.

Esteban-Cornejo, I., Martinez-Gomez, D., Garcia-Cervantes, L., Ortega, F. B., Delgado-Alfonso, A., CastroPiñero, J., \& Veiga, O. L. (2017). Objectively measured physical activity during physical education and school recess and their associations with academic performance in youth: The UP\&DOWN study. Journal of Physical Activity and Health, 14(4), 275-282. https://doi.org/10.1123/jpah.2016-0192

Fitron, M. (2020). Survei Tingkat Persepsi Siswa Terhadap Konsep Pendidikan Jasmani di Sekolah Menengah Atas. Sport Science and Health, 2(5), 264-271.

Feldman, R. (2012). Bio-behavioral synchrony: A model for integrating biological and microsocial behavioral processes in the study of parenting. Parenting, 12(2-3), 154-164. https://doi.org/10.1080/15295192.2012.683342

Harvey, S., Kirk, D., \& O’Donovan, T. M. (2014). Sport Education as a Pedagogical Application for Ethical Development in Physical Education and Youth Sport. Sport, Education and Society, 19(1), 41-62. https://doi.org/10.1080/13573322.2011.624594 
Kwon, E. H., \& Block, M. E. (2017). Implementing the Adapted Physical Education E-Learning Program Into Physical Education Teacher Education Program. Research in Developmental Disabilities, 69, 1829. https://doi.org/10.1016/j.ridd.2017.07.001

Lengkana, A. S., \& Sofa, N. S. N. (2017). Kebijakan Pendidikan Jasmani dalam Pendidikan. Jurnal Olahraga, 3(1), 1-12.

Marheni, E., Afrizal, S., \& Purnomo, E. (2019). Application of Character Building with Physical Education (CBPE). Suluah Bendang Jurnal Ilmiah Pengabdian Kepada Masyarakat, 20(1), $46-53$. https://doi.org/10.24036/sb.0400

Marhento, G. (2015). Pengaruh Persepsi Siswa Tentang Kompetensi Guru Mengajar dan Motivasi Belajar Terhadap Hasil Belajar IPA. Formatif, 1(3), 234808.

Mashuri, H. (2017). Persepsi Siswa Terhadap Pembelajaran Guru Pendidikan Jasmani di SMA Muhammadiyah Kediri. Jurnal SPORTIF: Jurnal Penelitian Pembelajaran, 3(1), 1-10. https://doi.org/10.29407/js_unpgri.v3i1.681

McEvoy, E., Heikinaro-Johansson, P., \& MacPhail, A. (2017). Physical education teacher educators' views regarding the purpose (s) of school physical education. Sport, Education and Society, 22(7), 812-824. https://doi.org/10.1080/13573322.2015.1075971

McLennan, N., \& Thompson, J. (2015). Quality physical education (QPE): Guidelines for policy makers. UNESCO Publishing.

MroczekADEF, D., SuperlakABD, E., KawczyńskiCEF, A., \& ChmuraAD, J. (2017). Relationships between motor abilities and volleyball performance skills in 15-year-old talent-identified volleyball players. Baltic Journal of Health and Physical Activity, 9(1), 17-27.

Muhtar, T., \& Dallyono, R. (2020). Character education from the perspectives of elementary school physical education teachers . Cakrawala Pendidikan, 39(2), 395-408. https://doi.org/10.21831/cp.v39i2.30647

Mutodi, P., \& Ngirande, H. (2014). The influence of students perceptions on mathematics performance. A case of a selected high school in South Africa. Mediterranean Journal of Social Sciences, 5(3), 431. https://doi.org/10.5901/mjss.2014.v5n3p431

Najichun, M., \& Winarso, W. (2017). Hubungan persepsi siswa tentang guru matematika dengan hasil belajar matematika siswa. Jurnal Psikologi Undip, 2(15), 139-146.

Novferma, N. (2016). Analisis kesulitan dan self-efficacy siswa SMP dalam pemecahan masalah matematika berbentuk soal cerita. Jurnal Riset Pendidikan Matematika, 3(1), 76-87. https://doi.org/10.21831/jrpm.v3i1.10403

Pambudi, M. I., Winarno, M. E., \& ... (2019). Perencanaan dan Pelaksanaan Pembelajaran Pendidikan Jasmani Olahraga Kesehatan. Jurnal Pendidikan: Teori, Penelitian, dan Pengembangan, 4(1), 110 116. http://dx.doi.org/10.17977/jptpp.v4i1.11906

Penney, D., \& Chandler, T. (2000). Physical education: what future (s)? Sport, Education and Society, 5(1), 71-87. https://doi.org/10.1080/135733200114442

Pieter, H. Z. (2018). Pengantar psikologi untuk kebidanan. Kencana.

Portwood, M. (2019). Dyslexia and physical education. Routledge.

Pujianto, D., Insanistyo, B., \& Sihombing, S. (2021). Physical Education in Bengkulu: Learning System in the Covid-19 Pandemic Era. In International Conference on Educational Sciences and Teacher Profession (ICETeP 2020) (Pp. 138-140). Atl, 138-140. 
Rahman, A., Ernawati, E., \& Ekanara, B. (2018). Profil kreativitas dan pemahaman konsep siswa pada subkonsep organel sel hewan dan tumbuhan. Biodidaktika: Jurnal Biologi dan Pembelajarannya, 13(2), 24-30. http://dx.doi.org/10.30870/biodidaktika.v13i2.3673

Rahman, I., Gani, R. A., \& Achmad, I. Z. (2020). Persepsi siswa pada pembelajaran pendidikan jasmani olahraga dan kesehatan tingkat SMA. Jurnal Pendidikan Olahraga, 9(2), 144-154. http://dx.doi.org/10.31571/jpo.v9i2.1898

Redawati, R., \& Asnaldi, A. (2017). Persepsi Guru-Guru Non Penjas terhadap Pembelajaran Pendidikan Jasmani Olahraga Kesehatan dan Rekreasi Gugus IV Sungai Jambu Kecamatan Pariangan. Sport Science, 17(1), 10-18. https://doi.org/10.24036/jss.v17i1.1

Saputra, I. D., \& Syafik, A. (2016). Pengaruh Persepsi Terhadap Prestasi Belajar Matematika Siswa Kelas VIII SMP/MTs Se-Kecamatan Gombong Kabupaten Kebumen. EKUIVALEN-Pendidikan Matematika, 21(2), 1-10.

Sarwono, S. W. (2010). Pengantar Psikologi Umum Jakarta. Rajawali Press.

Siregar, S. (2018). Meningkatkan kemampuan guru dalam menerapkan pembelajaran kontekstual melalui Focus Group Discussion (FGD) di SMK Negeri 1 Sirandorung tahun pelajaran 2017/2018. NUSANTARA: Jurnal Ilmu Pengetahuan Sosial, 5(1), 14-19. http://dx.doi.org/10.31604/jips.v5i1.2018.14-19

Stevens, S. R., \& Culpan, I. (2021). The joy of movement: the non-participant in physical education curriculum design. Curriculum Studies in Health and Physical Education, 12(1), 80-93. https://doi.org/10.1080/25742981.2021.1878918

Suherman, A. (2018). The implementation of character education values in integrated physical education subject in elementary school. SHS Web of Conferences, $42,45$.

Teodora-Mihaela, I., Veronica, M., \& Laurentiu-Gabriel, T. (2017). The importance of motion games in the psychomotor development of pre-schoolers during the physical education class. SHS Web of Conferences, 37, 1070. https://doi.org/10.1051/shsconf/20173701070

Triatna, C. (2015). Psikologi Organisasi Dalam Pendidikan. PT. Remaja Rosdakarya.

Wang, S.-J., Xu, D.-Q., \& Li, J.-X. (2017). Effects of regular Tai Chi practice and jogging on neuromuscular reaction during lateral postural control in older people. Research in Sports Medicine, 25(1), 111-117. https://doi.org/10.1080/15438627.2016.1258649

Wang, J. C., Liu, W. C., Chatzisarantis, N. L., \& Lim, C. B. (2010). Influence of perceived motivational climate on achievement goals in physical education: A structural equation mixture modeling analysis. Journal of Sport and Exercise Psychology, 32(3), 324-338. https://doi.org/10.1123/jsep.32.3.324

Wardana, A. N., \& Hairunnisa, S. E. W. (2018). Pengaruh Persepsi Siswa SMAN 2 Samarinda terhadap Minat dalam Memilih Universitas Mulawarman (Studi pada Siswa Kelas 3). E-Journal Ilmu Komunikasi, 6(4), 327-341.

Whitehead, M. (2013). What is the education in physical education. Debates in Physical Education, 22-36.

Xiong, X., Dalziel, K., Carvalho, N., Xu, R., \& Huang, L. (2021). Association between 24-hour movement behaviors and health-related quality of life in children. Quality of Life Research, 1-10. https://doi.org/10.1007/s11136-021-02901-6 